\title{
Shelf-life assessment of energy banana bar using acceleration method with critical moisture content approach
}

\author{
Riyanti EKAFITRI ${ }^{1 *}$ (D), Yose Rizal KURNIAWAN ${ }^{1}$, Dewi DESNILASARI ${ }^{1}$ (D), Diki Nanang SURAHMAN ${ }^{1}$ (D), \\ Ashri INDRIATI ${ }^{1}$ (D)
}

\begin{abstract}
The shelf-life of the product need to be evaluated according to the commercialization of the product. Shelf-life assessment of the product can be done using acceleration method (Accelerated Shelf-life Testing) with critical moisture content approach. This research used the acceleration method to predict the expired date of the energy bar based banana. This method required the data such as initial water content, critical moisture content, solid weight of the product, surface area of the packaging, permeability water vapor of the packaging, saturated water vapor pressure, and slope of the sorption isotherm curve. The result showed that the shelf life of banana bar products that was packaged using aluminium foil, aluma, and metalized plastics consecutively for 511.15; 458.72; and 80.95 days based on the acceleration method with the critical moisture content approach.
\end{abstract}

Keywords: critical moisture content; banana bar; shelf-life.

Practical Application: This method of research could be predicted shelf-life product of snack bar.

\section{Introduction}

Nowadays the demand of nutritious food product has been increased dramatically in the last decade. The needs of healthy, delicious and ready to eat product is increased according to the lifestyle. One of the ready to eat product was energy bar. Energy Bar is a nutritious product that contains of high macronutrient such as protein, fat, and carbohydrate in a bar shape. This product usually is consumed by people with high activity to maintain the calorie that they needed. This energy bar can make base on banana and banana flour (Norajit et al., 2011).

Indonesia is one of the biggest banana producers in Asia. About $50 \%$ banana production in Asia was produced in Indonesia (Astawan \& Kasih, 2008). Meanwhile, Banana is nutritious food contains dietary fiber and resistant starch (Musita, 2012). Futhermore, $100 \mathrm{~g}$ of banana contains of $75 \mathrm{~g}$ moisture content, $1.2 \mathrm{~g}$ protein, 0.2 fat, $23 \mathrm{~g}$ carbohydrate, and $0.6 \mathrm{~g}$ other substance (Eriyana et al., 2017). Banana is also rich of essential mineral such as magnesium, potassium, phospor, calcium, and $\mathrm{A}, \mathrm{B}$ vitamin (thiamin, riboflavine, niacine, and B6) (Wall, 2006; Aurore et al., 2009). When banana become flour, it's still has nutritious compound and also rich of resistant starch and dietary fiber. Green banana flour contain of $17.5 \%$ resistant starch and $14.5 \%$ dietary fiber that is good for healty intestine (Ovando-Martinez et al., 2009).

The development energy bar based banana already has been done (Rahman et al., 2011; Sarifudin et al., 2015; Ekafitri \& Isworo, 2014). The shelf-life of the product need to be evaluated according to be comerzialisation product. Moreover the expired date of the product is need to be labelled in the packaging of the product according to BPOM regulation number 312018.
This is related to the food safety as product quality assurance for consumers.

Shelf-life assessment of the product can be done using acceleration method (Accelerated Shelf-life Testing/ASLT) by storage the product in the extreme environment such as high temperature and humidity to expire the product. This method can be done in short time with high accuration compared with method that storage in the ambient temperature (Arpah, 2001). One of the Shelf-life model using ASLT method is using the critical moisture content approach. The method to assess the expired date of the perishable product that easy to absorb the water along the storage that is cause increasing the moisture content and change the texture of the product. This method is using the Labuza equation that need the initial moisture content, equilibrium moisture content, critical moisture content, packaging water vapor permeability constanta, surface area of the packaging, dry weight of the product in packaging, saturated vapor pressure, and slope of the MSI (moisture sorption isotherm) curve (Kusnandar et al., 2010).

Energy bar product that was produced has low moisture content and water activity and it categorized the biscuit product. Deterioration of biscuit quality was related to the texture of the product that is cause of water vapor absorb from the environment through the packaging. Research about the assessment shelf-life of the biscuit product using critical moisture content approach has been done in many research and the result showed that predicted expired date relative same with real expired date that claim by producer (Kusnandar et al., 2010; Diukareva et al., 2014; Cahyanti et al., 2016). Therefore this research used the 
acceleration method according the critical moisture content to predict the shelf life of of banana-energy bar.

\section{Materials and methods}

\subsection{Materials and equipment}

The main ingredient of the banana bar are green banana flour, "Ambon" banana puree, full cream milk, egg, margarine, sugar, sweetened condensed milk, salt, banana flavor, calcium propionate, potassium sorbate, desiccated coconut, emulsifier, baking powder, and micronutrient. Materials for analyzed was calcium oxide and $\mathrm{MgCl}_{2}, \mathrm{KI}, \mathrm{NaCl}, \mathrm{KCl}$, and $\mathrm{BaCl}_{2}$. Equipment were used in this research were dough mixer, baking sheet, oven, continuous sealer machine, texture analyzer, hygrometer, analytical balance, cup, and other glassware.

\subsection{Measurement of the initial moisture content (Mi) and critical moisture content (Mc) of the Product}

Initial moisture content (Mi) of the product before storage was evaluated using oven method (Association of Official Analytical Chemists, 1995). Critical moisture content was obtained by measure the moisture content of the product that is storage for 0 , $3,6,9$, and 12 hour in $28-30^{\circ} \mathrm{C}$ and $80-85 \%$. Sample was analyzed the crispness by organoleptic method with 32 untrained panelist using 7 points scale ranging from 7 (extremely crispy) to 1 (very not crispy). Simultaneously, the moisture content of the product was measured and stated in \% dry base $(\mathrm{db})$. Moisture content (axis) and crispness (y) of the product were plotted in linier curve and were stated in linier regression equation $\mathrm{y}=\mathrm{a}+\mathrm{bx}$. According to the linier regression equation, the critical moisture content of the product was detected (it was declared, when the crispness of the product was 3 scale crispy score). Moisture content of the product every hour was obtained using Oven Method 15 and the texture (hardness and crispness) was obtained using Texture Analyzer with 3 bend ring probe.

\subsection{Determination of equilibrium moisture content of the product}

The first step of the method was made the saturated salt solution to manage the relative humidity $(\mathrm{RH})$ of the desiccator. Saturated salt solution was used were $\mathrm{MgCl}_{2}, \mathrm{KI}, \mathrm{NaCl}, \mathrm{KCl}$, $\mathrm{BaCl}_{2}$ with the relative humidity range $32.4-90 \%$ (Table 1 ).

Moreover, $2 \mathrm{~g}$ grinding sample of banana bar (moisture content was $1.99 \% \mathrm{db}$ ) in porcelain pot (storage in calcium oxide

Table 1. RH values, and water activity (aw) of saturated salt at temperature $30^{\circ} \mathrm{C}$.

\begin{tabular}{ccc}
\hline Type saline & RH (\%) & Water Activity (aw) \\
\hline${ }^{*} \mathrm{MgCl}_{2}$ & 32.4 & 0.324 \\
${ }^{*} \mathrm{KI}$ & 68.0 & 0.680 \\
${ }^{*} \mathrm{NaCl}$ & 74.9 & 0.749 \\
${ }^{*} \mathrm{KCl}$ & 83.6 & 0.836 \\
${ }^{*}{ }^{*} \mathrm{BaCl}_{2}$ & 90.0 & 0.90 \\
\hline
\end{tabular}

*Bell \& Labuza (2000); ${ }^{* *}$ Greenspan (1977); ${ }^{* * *}$ Pakpahan (2017). for 2 weeks) was stored in desiccator with saturated salt solution. After that, the sample was weight every day in the same time until the weight was constant. Constant weight indicated that moisture content was in equilibrium. Equilibrium was attained when three successive weight measurements did not differ more than $2 \mathrm{mg} / \mathrm{g}$ for sample storage in $90 \%$ relative humidity $\left(\mathrm{MgCl}_{2}\right.$, $\mathrm{KI}, \mathrm{NaCl}, \mathrm{KCl}$ salt solution) and less than $10 \mathrm{mg} / \mathrm{g}$ for sample that was storage in $>90 \%$ relative humidity $\left(\mathrm{BaCl}_{2}\right.$ salt solution) (Kusnandar et al., 2010).

Sample that was already reach the constant weight was measured the moisture content using oven method (Badan Standarisasi Nasional, 2011) to obtained equilibrium moisture content $(\mathrm{Me})$. Moreover, it was plotted in sorption isotherms curve with moisture content, relative humidity or aw was used mathematical equation to find the best curve. Equations model that has been used were Guggenheim-Anderson-de Boer (GAB), Hasley, Chen-Clayton, Henderson, Caurie, dan Oswin (Bell \& Labuza, 2000). Analyzed the best model was evaluated by mean relative determination (MRD). This was done by compared the real value moisture content with the predicted value. If the MRD is less than 5, the model is showed the real condition; If the MRD was more than 5 and less than 10 , it was categorized rather right; if the MRD value more than 10, the model was categorized inaccurate to describe the real condition of the product. Model with the lowest MRD value was declared as fit model to assessment the shelf-life of the banana bar.

\subsection{Analyzed the permeability of the packaging $(k / x)$ (Kurniawan, 2018)}

This was obtained according standard method ASTM F-1249 (American Society for Testing Materials). Water vapor permeability of the aluma, aluminium foil, and metalized packaging was used permatranmocon $\mathrm{W}^{\star} 3 / 31$ in $100^{\circ} \mathrm{F}\left(37.8^{\circ} \mathrm{C}\right)$. Aluma, aluminium foil, and metalized was cut according the mold and then obtained the thickness. Sample of packaging was placed in the cell of the measurement tools. The value of thickness and spacious of the packaging, testing temperature, humidity, and air flow rate inside the chamber ( $\mathrm{RH} 0 \%$ ) was obtained. Wet nitrogen gas was flown outside the chamber (RH 100\%). Test sample (plastic) inside the cell became the delimiter between the wet and dry nitrogen. The difference of the pressure results in the diffusion of the gas to the low pressure (inside chamber). Water vapor that was diffusion to the packaging will be carried by dry nitrogen to the infrared sensor, so it will detect the value and the rate of water vapor could be count. The testing will be finished when its steady state and the value of the rate of water vapor was showed the constant value. In the end of the testing, the value of the water vapor transmission rate (WVTR) $\mathrm{g} / \mathrm{m}^{2} /$ day was obtained. The value of the permeability of the packaging $(\mathrm{k} / \mathrm{x})$ was counting by dividing the WVTR value with the multiplication pure vapor pressure $(\mathrm{Po})$ in the testing period with relative humidity value.

\subsection{The slope value of the sorption isotherm curve (b)}

The value of the sorption isotherm curve (b) was determined in the linier area (between the initial moisture content (Mi) and 
critical moisture content (Mc)) (Bell \& Labuza, 2000). Mi and Mc point which in sorption isotherm curve was selected will be linked with linier line, and result in the linier equation $y=a+b x$. The $b$ value of the linier equation was the value of the slope of the sorption isotherm curve.

\subsection{The solid weight of packaging (Ws) and measurement the surface area the packaging (A)}

The solid weight of the packaging was determined with weight the initial weight banana bar in the packaging (Ws) which determined by using equation 1 , and the value was corrected according the initial moisture content.

$\%$ solid $=(1-$ wet moisture content $) \times 100 \%$

Ws $(\mathrm{g})=\mathrm{W} \times(\%$ solid $/ 100)$

Surface area measurement was determined used the primer packaging of the banana bar and it was expressed in $\mathrm{m}^{2}$.

\subsection{Assessment the shelf-life banana bar}

Assessment the shelf-life of the banana bar was determined with entered the data that already we have in the equation 2 :

$\mathrm{T}=\frac{\ln [(\mathrm{Me}-\mathrm{Mi}) /(\mathrm{Me}-\mathrm{Mc})]}{(\mathrm{k} / \mathrm{x} \mathrm{A} /(\mathrm{Ws}) \mathrm{Po} / \mathrm{b})}$

annotation: $\mathrm{T}=$ shelf-life (days); $\mathrm{ln}=$ natural logarithm; $\mathrm{Me}=$ equilibrium of the moisture content $(\% \mathrm{db}) ; \mathrm{Mi}=$ initial moisture content $(\% \mathrm{db}) ; \mathrm{Mc}=$ critical moisture content $(\% \mathrm{db})$; Ws = Solid weight of the packaging $(\mathrm{g}) ; \mathrm{A}=$ surface area of the packaging $(\mathrm{m} 2) ; \mathrm{k} / \mathrm{x}=$ permeability water vapor of the packaging $\left(\mathrm{g} / \mathrm{m}^{2}\right.$.day.mmHg); Po = saturated water vapor pressure $(\mathrm{mmHg})$; $\mathrm{b}=$ slope of the sorption isotherm curve.

Assessment of the shelf-life of the product was determined in $30{ }^{\circ} \mathrm{C}$ with relative humidity $80 \%$ in the three type of the packaging (aluma, aluminium foil, and metalized plastic). Shelf-life was determined in unit of month that is assumed 1 month was 30 days.

\section{Result and discussion}

\subsection{Initial and critical moisture content}

The initial moisture content of the product (Mi) banana bar was $6.23 \% \mathrm{db}$. This results are higher than the moisture content of banana bar with the addition of nuts which is 3.36-
$6.05 \%$ (Ekafitri \& Isworo, 2014) and the standard of biscuit products is less than 5\% (Badan Standarisasi Nasional, 2018), but lower than banana based snack bar which is $17.58-30.01 \%$ (Sarifudin et al., 2015). Differences in results may be caused by differences in formulation, product dimensions, baking time and baking temperature. The weight of a banana bar package is $20 \mathrm{~g}$ and dry weight of the material (Ws) is $18.83 \% \mathrm{db}$.

Table 2 shows changes in moisture content, texture values, and banana bar crispness score. Based on the table, it can be seen that the longer the shelf time, the moisture content of the product increases (6.23-12.12\%) and the hardness, crispness, and crispness score decrease (13998.81-5204.84 gf; 30.75-29, 01 mm; 5.27-2.73). Critical moisture content is obtained when the product gets a crispy score of 3.0 which is rather crisp. Based on Table 2, we obtained curve of moisture content and crispness score with the equation is $\mathrm{y}=-1,792 \mathrm{x}+15.06$ ( $\mathrm{y}$ axis is the moisture content and $\mathrm{x}$ axis is the crispness score). According to the equation, critical moisture content of the banana bar product is $0.0969 \mathrm{~g} \mathrm{H}_{2} \mathrm{O} / \mathrm{g}$ solid. This means that banana bar can not accepted by panelist when its crispness reach moisture content $0.0969 \mathrm{~g} \mathrm{H}_{2} \mathrm{O} / \mathrm{g}$ solid. This is different from the critical moisture content of soft and hard dough biscuits. This is different from the critical moisture content of soft and hard dough biscuits which has critical moisture content 0.064 and $0.069 \mathrm{~g} \mathrm{H}_{2} \mathrm{O} / \mathrm{g}$ solid (Kusnandar et al., 2010). It can be caused by differences in initial moisture content of the product.

\subsection{Curves, mathematical modeling, and slope of moisture sorption isotherm curve of banana bar}

Sorption isotherm curve is used to get the equilibrium moisture content $(\mathrm{Me})$ measured at various $\mathrm{RH}$ salt. During storage, the banana bar sample exhibited an increase in weight indicating that the banana bar was undergoing a process of vapor adsorption because aw (water activity) products are lower than the environment. During the storage process, the vapor moves from environment to product until an equilibrium condition is reached. This is indicated by the weight of the sample being constant.

Moisture sorption isotherms can be classified into types I, II, and III based on the curve shape (Yaptenco et al., 2017). The moisture sorption isotherms of banana bar resembles a sigmoid biscuit curve (Kusnandar et al., 2010) and chicken wheat crips (Bhardwaj et al., 2017) that are classified as type II. Figure 1 shows the higher water activity (aw) is proportional with equilibrium moisture content. It is caused by the pressure of water vapor in the material increased following an increase in water vapor pressure around (Sharma et al., 2009). Equilibrium moisture content with equilibrium $\mathrm{RH}$ value or $\mathrm{a}_{\mathrm{w}}$ are also plotted

Table 2. Changes in moisture content, texture values, and banana bar crispness score levels.

\begin{tabular}{|c|c|c|c|c|}
\hline \multirow{2}{*}{ Shelf time (hour) } & \multirow{2}{*}{${ }^{\star}$ Crispness score } & \multirow{2}{*}{$\begin{array}{l}\text { moisture content } d b \\
\quad\left(g \mathrm{H}_{2} \mathrm{O} / \mathrm{g} \text { solid }\right)\end{array}$} & \multicolumn{2}{|c|}{ Texture } \\
\hline & & & hardness $(g f)$ & Crispness $(\mathrm{mm})$ \\
\hline 0 & 5.27 & 0.0623 & 13998.81 & 30.75 \\
\hline 3 & 4.00 & 0.0742 & 11380.13 & 30.17 \\
\hline 6 & 3.30 & 0.0814 & 10779.63 & 29.89 \\
\hline 9 & 3.07 & 0.0849 & 8629.42 & 29.86 \\
\hline 12 & 2.73 & 0.1212 & 5204.84 & 29.01 \\
\hline
\end{tabular}

${ }^{\star}$ Score crispness scale 1 (very not crispy) -7 (extremely crispy). 


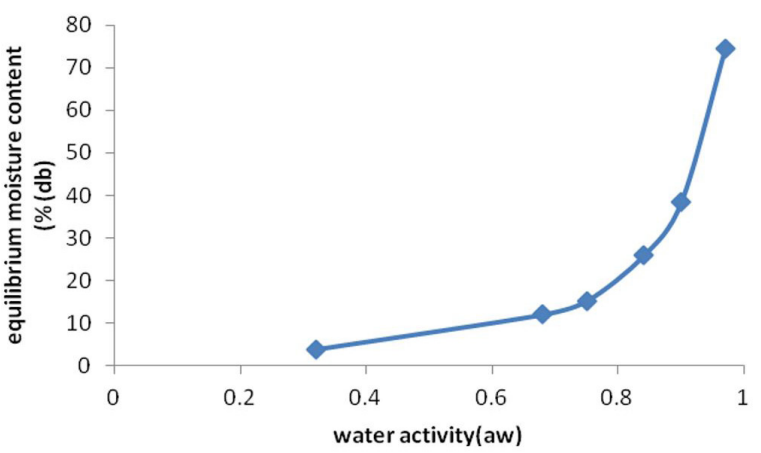

Figure 1. Moisture sorption isotherm curves of banana bar.

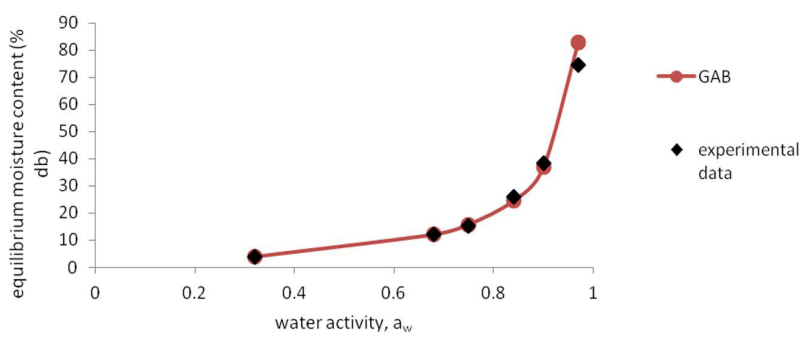

Figure 2. The accuracy of GAB modeling for banana bar products.

Table 3. Mathematical equations and MRD values of banana bar.

\begin{tabular}{ccr}
\hline $\begin{array}{c}\text { Mathematical } \\
\text { model }\end{array}$ & Mathematical equation & MRD \\
\hline GAB & $M_{e}=12.706 \mathrm{a}_{\mathrm{w}} /\left(1-0.972 \mathrm{a}_{\mathrm{w}}\right)\left(1+1.634 \mathrm{a}_{\mathrm{w}}\right)$ & 4.07 \\
Hasley & $\log \left(\ln \left(1 / \mathrm{a}_{\mathrm{w}}\right)=-1.06464-0.52118 \log M_{e}\right.$ & 14.23 \\
Chen-Clayton, & $\ln \left(\ln \left(1 / \mathrm{a}_{\mathrm{w}}\right)\right)=-0.29451-4.59426 M_{e}$ & 71.18 \\
Henderson, & $\log \left(\ln \left(1 /\left(1-\mathrm{a}_{\mathrm{w}}\right)\right)\right)=0.67732+0.72422 \log M_{e}$ & 9.55 \\
Caurie, & $\ln M_{e}=-4.85947+4.32157 \mathrm{a}_{\mathrm{w}}$ & 14.14 \\
Oswin & $\ln M_{e}=-2.65518+0.71868 \ln \left(\mathrm{a}_{\mathrm{w}} /\left(1-\mathrm{a}_{\mathrm{w}}\right)\right)$ & 7.99 \\
\hline
\end{tabular}

Table 4. The water vapor permeability of packaging banana bar.

\begin{tabular}{cc}
\hline Packaging type & $\begin{array}{c}\text { Packaging permeability } \\
\left(\mathrm{gH}_{2} \mathrm{O} / \mathrm{m}^{2} . \text { day. } \mathrm{mmHg} \mathrm{Hg}^{2}\right)\end{array}$ \\
\hline aluminium foil & 0.0035 \\
aluma & 0.0039 \\
metalized plastics & 0.0221 \\
\hline
\end{tabular}

in several models of mathematical equations to get the best curve models seen from the MRD value (Table 3 ).

MRD values generated from Guggenheim-Anderson-DE Boer (GAB) equation, Hasley, Chen-Clayton, Henderson, Caurie, and Oswin, respectively: 4.07; 14.23; 71.18; 9.55; 14,14; 7.99. Based on smallest MRD value (Table 3 ) and it can be seen that the equilibrium moisture content appropriate with $\mathrm{GAB}$ equation. The accuracy of GAB modeling can be seen in Figure 2. GAB is expressed in accordance with several types of food such as biscuits, chicken wheat crips, and extrudate products (Bhardwaj et al., 2017; Guiné et al., 2014; Wani \& Kumar, 2016). GAB model is known as a superior model because its success in modeling many food products in a wide " $a$ " range of 0.1-0.9 (Kurniawan, 2018; Bhardwaj et al., 2017).

Slope sorption isotherm curve values taken from areas that pass the initial moisture content (Mo) on the model of the water sorption curves (Figure 2). Based on the graph, slope of curve (b) for banana bar is 0.2403 .

\subsection{Water vapor permeability $(k / x)$ and packaging area $(A)$}

Permeability of packaged water vapor $(\mathrm{k} / \mathrm{x})$ is the speed or rate of water vapor transmission through a unit area of material with a flat surface with a certain thickness as a result of differences in water vapor pressure between the product surfaces at specific conditions of temperature and RH (Kusnandar et al., 2010). The vapor permeability value of packaging for banana bar products was tested on three types of packaging including aluminium foil, aluminium (with PE plastic and laminated), and metalized plastics (Table 4 ). The lowest packaging water vapor permeability is aluminium foil packaging $\left(0.0035 \mathrm{gH}_{2} \mathrm{O} / \mathrm{m}^{2}\right.$.day.mmHg $)$ and the largest packaging water vapor permeability is metalized plastic packaging $\left(0.0221 \mathrm{gH}_{2} \mathrm{O} / \mathrm{m}^{2}\right.$.day. $\left.\mathrm{mmHg}^{2}\right)$. The difference of packaging water vapor permeability can be due to differences in the composition of packaging material, thickness, and size of the packaging pores. The thinner packaging and the larger pores of the packaging, the higher the water vapor permeability of packaging means the packaging more easily passed by water vapor. The thickness of the aluminium foil packaging, aluma, and metalized plastics are $75 \mu \mathrm{m}, 11.4 \mu \mathrm{m}$, and $52.7 \mu \mathrm{m}$. Packaging with lower water vapor permeability is thought to provide a longer

Table 5. Data and results of banana bar shelf life calculations based on the critical water content approach.

\begin{tabular}{lccc}
\hline \multicolumn{1}{c}{ Parameter } & \multicolumn{2}{c}{ Packaging type } \\
\cline { 2 - 4 } & aluminium foil & aluma & 0.0623 \\
\hline Initial water content $\left(\mathrm{g} \mathrm{H}_{2} \mathrm{O} / \mathrm{g}\right.$ solid) $(\mathrm{Mo})$ & 0.0623 & 0.0623 & 0.0969 \\
Critical water content $\left(\mathrm{g} \mathrm{H}_{2} \mathrm{O} / \mathrm{g}\right.$ solid)(Mc) & 0.0969 & 0.0969 & 1.2339 \\
$(\mathrm{Me}-\mathrm{Mo}) /(\mathrm{Me}-\mathrm{Mc})$ & 1.2339 & 0.2339 & 0.2102 \\
$\ln (\mathrm{Me}-\mathrm{Mo}) /(\mathrm{Me}-\mathrm{Mc})$ & 0.2102 & 0.2403 & 0.2403 \\
Slope sorption isotherm curve & 0.2403 & 0.2446 & 0.2446 \\
Equilibrium water content $\left(\mathrm{g} \mathrm{H}_{2} \mathrm{O} / \mathrm{g}\right.$ solid) $(\mathrm{Me})$ & 0.2446 & 0.0039 & 0.0221 \\
Packaging permeability $\left(\mathrm{g} / \mathrm{m}^{2}\right.$.day.mmHg) & 0.0035 & 0.0167 & 0.0167 \\
Packaging area $\left(\mathrm{m}^{2}\right)$ & 0.0167 & 18.8260 & 18.8260 \\
Solid weight per package $(\mathrm{g}$ solid) & 18.8260 & 31.8240 & 31.8240 \\
Saturated vapor pressure at $30^{\circ} \mathrm{C}(\mathrm{mmHg})$ & 31.8240 & 458.72 & 80.95 \\
Shelf life $($ days $)$ & 511.15 & 15.29 & 2.70 \\
Shelf life (month) & 17.04 & & \\
\hline
\end{tabular}


Ekafitri et al.

Table 6. Data and results of banana bar shelf life calculations based on the critical water content approach.

\begin{tabular}{|c|c|c|c|}
\hline \multirow{2}{*}{ Parameter } & \multicolumn{3}{|c|}{ Packaging type } \\
\hline & aluminium foil & aluma & metalized plastics \\
\hline Initial water content $\left(\mathrm{g} \mathrm{H}_{2} \mathrm{O} / \mathrm{g}\right.$ solid $)(\mathrm{Mo})$ & 0.0623 & 0.0623 & 0.0623 \\
\hline Critical water content $\left(\mathrm{g} \mathrm{H}_{2} \mathrm{O} / \mathrm{g}\right.$ solid $)(\mathrm{Mc})$ & 0.0969 & 0.0969 & 0.0969 \\
\hline$(\mathrm{Me}-\mathrm{Mo}) /(\mathrm{Me}-\mathrm{Mc})$ & 1.2339 & 1.2339 & 1.2339 \\
\hline $\ln (\mathrm{Me}-\mathrm{Mo}) /(\mathrm{Me}-\mathrm{Mc})$ & 0.2102 & 0.2102 & 0.2102 \\
\hline Slope sorption isotherm curve & 0.2403 & 0.2403 & 0.2403 \\
\hline Packaging permeability $\left(\mathrm{g} / \mathrm{m}^{2}\right.$.day.mmHg) & 0.0035 & 0.0039 & 0.0221 \\
\hline Packaging area $\left(\mathrm{m}^{2}\right)$ & 0.0167 & 0.0167 & 0.0167 \\
\hline Solid weight per package (g solid) & 18.8260 & 18.8260 & 18.8260 \\
\hline Saturated vapor pressure at $30^{\circ} \mathrm{C}(\mathrm{mmHg})$ & 31.8240 & 31.8240 & 31.8240 \\
\hline Shelf life (days) & 511.15 & 458.72 & 80.95 \\
\hline
\end{tabular}

shelf life (Yaptenco et al., 2017). Based on Table 5, it is known that aluminium foil and aluma packaging has a low vapor permeability of packaging so it is recommended to use banana bar packaging when compared to metalized plastic packaging. Metalized plastic is a type of packaging most easily by passed moisture, so less is recommended to pack banana bar even though the cost of production is less expensive types of packaging.

Banana bar surface area (A) was obtained from manual measurement of packaging area three times. The surface area for packing banana bar products with a net weight of $20 \mathrm{gr}(\mathrm{wb}$ ) is $0.0167 \mathrm{~m}^{2}$.

\subsection{Determination of shelf life banana bar}

Data and calculation results (Equation 2) for the shelf life of banana bar products that use three types of packaging (aluminium foil, aluma, and metalized plastics) are shown in Table 6. Predicted shelf life of banana bar products with aluminium foil packaging (511.15 days/17.04 months) and aluma (458.72 days/15.29 months) longer than those packaged with metalized plastic ( 80.95 days/2.7 months). Therefore banana bar products are recommended to use aluminium foil or alumna packaging types.

Prediction of shelf life of banana bars with all three types of packaging is lower compared to the arhenius method at $30^{\circ} \mathrm{C}$, for the parameter water content is 134.29 weeks or 938 days but a higher shelf life seen from the peroxide number is 13.18 days (Desnilasari et al., 2014). Biscuits added with fruit powder have a shelf life of 42 days (Thivani et al., 2016) lower than shelf life of bar products made from banana flour in this study. Banana bars packed with metalized plastics have a shelf life approaching biscuits with metalized polypropylene packaging from the research of Nadarajah \& Thevaki (2015) for 84 days.

\section{Conclusion}

The shelf life of banana bar products are packaged using aluminium foil, aluma, and metalized plastics consecutively for $511.15 ; 458.72$; and 80.95 days based on the acceleration method with the critical water content approach. Shelf life is influenced by factors such as initial water content, critical water content, product dry weight, package surface area, package permeability, saturated vapor pressure, and slope sorption isotherm curve.

\section{Acknowledgements}

The authors are grateful for funding through "IPTEK untuk Daerah" from the Indonesian Institute of Sciences, and for the use of experimental facilities at the Research Center for Appropriate Technology.

\section{References}

Arpah, M. (2001). Buku Dan Monograf Penentuan Kadaluarsa Produk Pangan. Bogor: Institut Pertanian Bogor.

Association of Official Analytical Chemists - AOAC. (1995). Official methods of analysis of the Association of Official Analytical Chemist (14th ed.). Arlington: AOAC.

Astawan, M., \& Kasih, A. L. (2008). Kasiat Warna Warni Makanan. Jakarta: PT Gramedia Pustaka Utama.

Aurore, G., Parfait, B., \& Fahrasmane, L. (2009). Bananas, raw materials for making processed food products. Trends in Food Science \& Technology, 20(2), 78-91. http://dx.doi.org/10.1016/j.tifs.2008.10.003.

Badan Standarisasi Nasional - BSN. (2011). SNI 2973:2011: biskuit. Jakarta.

Badan Standarisasi Nasional - BSN. (2018). Rancangan Standar Nasional Indonesia No. 2973-2018, biskuit. Jakarta.

Bell, L., \& Labuza, T. (2000). Moisture sorption: practical aspects of isotherm measurement and use. St. Paul: American Association of Cereal Chemists.

Bhardwaj, S., Shiby, V. K., Pandey, M. C., \& Gopalan, N. (2017). Moisture sorption characteristics of ready-to-eat chicken wheat crisps prepared using resistant starch and chicken powder with wheat flour. Defence Life Science Journal, 2(2), 163-168. http://dx.doi. org/10.14429/dlsj.2.11378.

Cahyanti, M. N., Hindarto, J., \& Lestario, L. N. (2016). Pemodelan isoterm sorpsi air biskuit coklat menggunakan persamaan caurie. Jurnal Aplikasi Teknologi Pangan, 5(2), 51-53.

Desnilasari, D., Diki, N.S., \& Rohmah, L. (2014). Pendugaan Umur Simpan Produk Foodbar Berbasis Pisang. In. Prosiding Seminar 
Nasional dan Workshop: Peningkatan Inovasi dalam Menanggulangi Kemiskinan. Subang: Balai Besar Pengembangan Teknologi Tepat Guna-LIPI.

Diukareva, G., Pak, A., \& Gasanova, A. (2014). Determination of storage conditions for new biscuits using their sorption isotherms. Ukrainian Food Journal, 3(2), 249-256.

Ekafitri, R., \& Isworo, R. (2014). Pemanfaatan Kacang-Kacangan sebagai Bahan Baku Sumber Protein Untuk Pangan Darurat. Jurnal Pangan, 23(2), 134-145.

Eriyana, E., Syam, H., \& Jamaluddin, J. P. (2017). Quality of bananas dodol by substituting different types of bananas. Jurnal Pendidikan Teknologi Pertanian, 3(1), 34, 3, 34-41. http://dx.doi.org/10.26858/ jptp.v3i1.5195.

Greenspan, L. (1977). Humidity fixed points of binary saturated aqueous solutions. Journal of Research of the National Bureau of Standards, 81A(1), 89-96. http://dx.doi.org/10.6028/jres.081A.011.

Guiné, R., Barroca, M. J., Pereira, D., \& Correia, P. M. R. (2014). Adsorption isotherms of Maria biscuits from different brands. Journal of Food Process Engineering, 37(3), 329-337. http://dx.doi. org/10.1111/jfpe.12089.

Kurniawan, Y. R. (2018). Pendugaan umur simpan beras analog. Bogor: Bogor Agricultural Institute.

Kusnandar, F., Adawiyah, D. R., \& Fitria, M. (2010). Accelerated shelflife testing of biscuits using a critical moisture content approach. Jurnal Teknologi dan Industri Pangan, 21(2), 1-6.

Musita, N. (2012). Kajian kandungan dan karakteristiknya pati resisten dari berbagai varietas pisang. Jurnal Dinamika Penelitian Industri, 23(1), 57-65

Nadarajah, S., \& Thevaki, M. (2015). Influence of storage conditions on the quality characteristics of wheat-defatted coconut flour biscuits packed in metalized polypropylene. International Journal of Engineering Research \& Technology, 4(07), 948-951.

Norajit, K., Gu, B., \& Ryu, G. (2011). Effects of the addition of hemp powder on the physicochemical properties and energy bar qualities of extruded rice. Food Chemistry, 129(4), 1919-1925. http://dx.doi. org/10.1016/j.foodchem.2011.06.002.
Ovando-Martinez, M., Sáyago-Ayerdi, S., Agama-Acevedo, E., Goñi, I., \& Bello-Pérez, L. A. (2009). Unripe banana flour as an ingredient to increase the undigestible carbohydrates of pasta. Food Chemistry, 113(1), 121-126. http://dx.doi.org/10.1016/j.foodchem.2008.07.035.

Pakpahan, N. (2017). Perilaku Isotermis Sorpsi Air Dan Perubahan Fisik Kerupuk Tapioka Selama Penyimpanan (Thesis). Sekolah Pascasarjana Institut Pertanian Bogor, Bogor

Rahman, T., Luthfiyanti, R., \& Ekafitri, R. (2011). Optimasi Proses Pembuatan Food Bar Berbasis Pisang. In National Seminar on Research and PKM Science, Technology, and Health. Bandung, Indonesia.

Sarifudin, A., Ekafitri, R., Surahman, D. N., \& Putri, S. K. D. F. A. (2015). Effect of egg concentration on proximate, water activity (aw) and textural properties of banana (Musa paradisiaca) snack bar. AGRITECH, 35(1), 1-8. http://dx.doi.org/10.22146/agritech.9413.

Sharma, P., Singh, R. R. B., Singh, A. K., Patel, A. A., \& Patil, G. R. (2009). Sorption isotherms and thermodynamics of water sorption of ready-to-use Basundi mix. Lebensmittel-Wissenschaft + Technologie, 42(1), 441-445. http://dx.doi.org/10.1016/j.lwt.2008.04.010.

Thivani, M., Mahendran, T., \& Kanimoly, M. (2016). Study on the physico-chemical properties, sensory attributes and shelf life of pineapple powder incorporated biscuits. Ruhuna Journal of Science, 7(2), 32-42. http://dx.doi.org/10.4038/rjs.v7i2.17.

Wall, M. M. (2006). Ascorbic acid, vitamin A, and mineral composition of banana (Musa sp. ) and papaya (Carica papaya) cultivars grown in Hawaii. Journal of Food Composition and Analysis, 19(5), 434-445. http://dx.doi.org/10.1016/j.jfca.2006.01.002.

Wani, S. A., \& Kumar, P. (2016). Moisture sorption isotherms and evaluation of quality changes in extruded snacks during storage. Lebensmittel-Wissenschaft + Technologie, 74, 448-455. http://dx.doi. org/10.1016/j.lwt.2016.08.005.

Yaptenco, K. F., Pardua, S. N., \& Duque, J. A. C. (2017). Moisture sorption isotherms and shelf life prediction for whole dried sandfish (Holothuria scabra). Agricultural Engineering International: CIGR Journal, 19(2), 176-186. 